J. Japan. Soc. Hort. Sci. 51(1) : 29-34. 1982.

\title{
Differential Water Tolerance and Ethanol Accumulation in Prunus Species under Flooded Conditions ${ }^{1}$
}

\author{
Fusao Mizutani ${ }^{2}$, Masahiko Yamada ${ }^{3}$ and Takashi Tomana \\ College of Agriculture, Kyoto University, Kyoto 606
}

\begin{abstract}
Summary
The effect of waterlogging on ethanol accumulation in the stems and roots of water sensitive and tolerant species of Prunus was examined. No or little accumulation of ethanol was found in the fine roots, but a close correlation was apparent between ethanol accumulation in the tap roots and stems and the sensitivity to waterlogging. A rapid ethanol accumulation was found in peach (Prunus persica Batsch) and Japanese apricot (P.mume Sieb. et Zucc.), while a slight accumulation in Japanese plum (P. salicina Lindl.) and little in P. japonica Thunb.

Peach trees grafted on $P$. japonica rootstocks showed the greater tolerance and much less ethanol accumulation in the roots and stems than those on peach rootstocks.

A soil drench of aqueous ethanol at concentrations of 2,7 and $20 \%$ reduced the shoot growth of young peach and P.japonica seedlings. P.japonica showed a slightly greater tolerance to $7 \%$ ethanol application, but no marked difference in the injury symptoms was observed between the two species.
\end{abstract}

\section{Introduction}

Rowe and Beardsell (9) tabulated water tolerance of Prunus species by cross-referring many literatures in their review. Prunus species vary in their water tolerance from intermediate (plum) to sensitive (apricot, peach and almond). Mizutani et al. (7) compared water tolerance of Prunus species in order to select water tolerant rootstocks for peach. They found that P.japonica is an extremely tolerant species and compatible with many peach scion cultivars. 'Ökubo' peach trees on P.japonica are dwarfed(8).

Ethanol accumulation under anaerobic conditions is well known in various plant tissues. Crawford (4) reported that there was an increase in ethanol production and ethanol dehydrogenase activity in roots of plant species whose growth was reduced by waterlogging.

\footnotetext{
1 Received for publication February 19, 1982.

2 Present address : College of Agriculture, Ehime University, Matsuyama 790

3 Present address : Akitsu Branch, Fruit Tree Research Station, Hiroshima 729-24
}

In this study we investigated whether the differential water tolerance of Prunus species is related to the ethanol accumulation in the tissues under flooded conditions. The relationship between water tolerant and sensitive rootstocks and ethanol accumulation in the shoots and roots of peach trees was also examined. In addition, the effect of a soil drench of aqueous ethanol on the shoot growth of tolerant and sensitive species was compared.

\section{Materials and Methods}

In the first experiment, 2 or 3-year-old seedlings and cuttings of 4 Prunus species (P.persica, P.mume, P.salicina and $P$. japonica) were grown in $18-\mathrm{cm}$ plastic pots. They were waterlogged for 10 days from May 29, 1979.

Their fine roots and upper and lower stems were collected after 0,3,6 and 10 days of flooding. Upper stems were defined as the portions of stem extending $10 \mathrm{~cm}$ down from the shoot tips. Lower stems were defined as those extending upward $5 \mathrm{~cm}$ from the soil surface. In another trial, 2 or $3-$ 
year-old seedlings and cuttings of $P$. persica. $P$. mume and P. japonica grown in $18 \mathrm{~cm}$ plastic pots were waterlogged for 18 days from June 29, 1979. Their tap roots and lower stems were collected after 0,6,12 and 18 days of flooding. One or $2 \mathrm{~g}$ of the tissues was immediately homogenized in acetone and the homogenate was stored in a sealed vial in a freezer until analysis. For measurement of ethanol content, $2 \mu 1$ of the supernatant of homogenate was directly injected into a gaschromatograph(Shimadzu GC $6 \mathrm{~A}, 1 \mathrm{~m} \times 3 \mathrm{~mm}$ i. d. glass column packed with Porapak Q, detector equipped with FID). Injury symptoms of the above ground parts due to waterlogging were estimated by giving a score of $O$ (no visible injury) to 5 (tree death), based on the degree of cessation of shoot growth, leaf wilting, chlorosis and abscission.

In the second experiment, three 2-yearold peach cultivars grafted on peach and P. japonica rootstocks were planted in $24 \mathrm{~cm}$ pots in spring, 1979. They were waterlogged for 8 days in early autumn, 1979. Ethanol content in the upper and lower stems and tap roots was measured by the same method as described above.

In the third experiment, 1-year-old peach and $P$. japonica seedlings grown in $15 \mathrm{~cm}$ plastic pots were used to examine the effect of a soil drench of ethanol on their shoot growth. Aqueous ethanol at concentrations of $0,2,7$ and $20 \%$ was applied to the pots at the beginning of the experiment and 2 days later $(100 \mathrm{ml} /$ pot each treatment $)$. The shoot growth was measured at weekly intervals.

\section{Results and Discussion}

Fig. 1 shows a rapid accumulation of ethanol in the upper and lower stems of peach and Japanese apricot(both sensitive) in response to waterlogging. In contrast, no or little ethanol accumulation was observed in

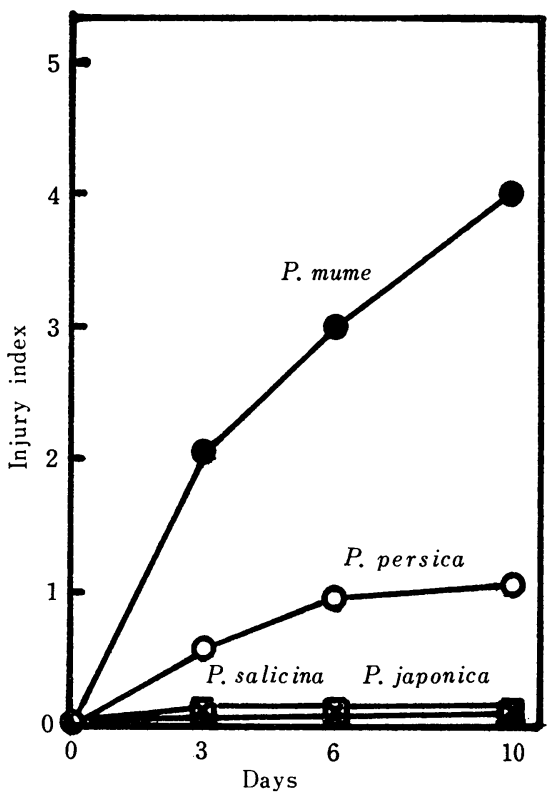

Fig. 2. Effect of waterlogging on in jury symptoms of the above ground parts of Prunus species. Plants were waterlogged for 10 days from May 29, 1979. Injury index : $0=$ no visible in jury, $5=$ plant death.
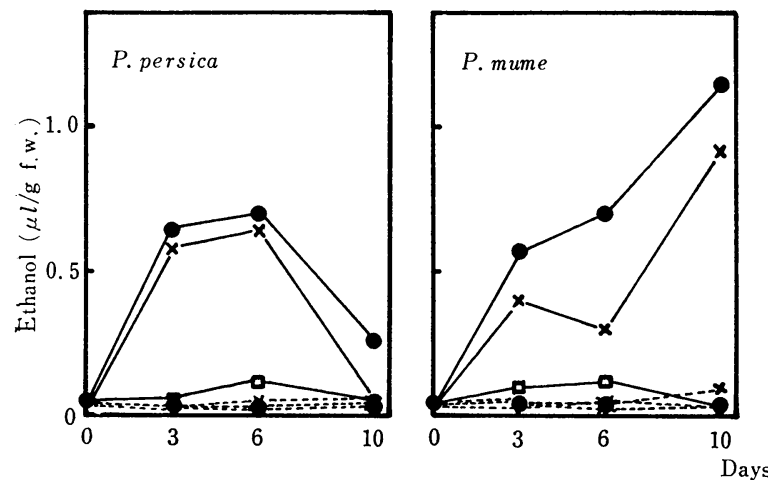

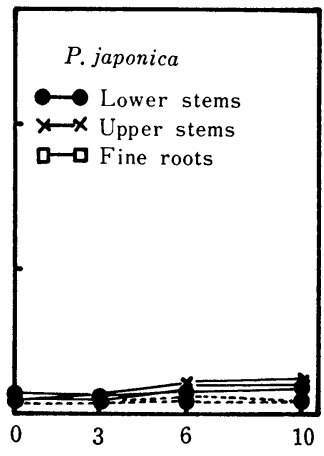

Fig. 1. Effect of waterlogging on ethanol accumulation in the stems and fine roots of Prunus species. Solid and dotted lines represent fooded and control plots, respectively. Plants were waterlogged for 10 days from May 29, 1979. 

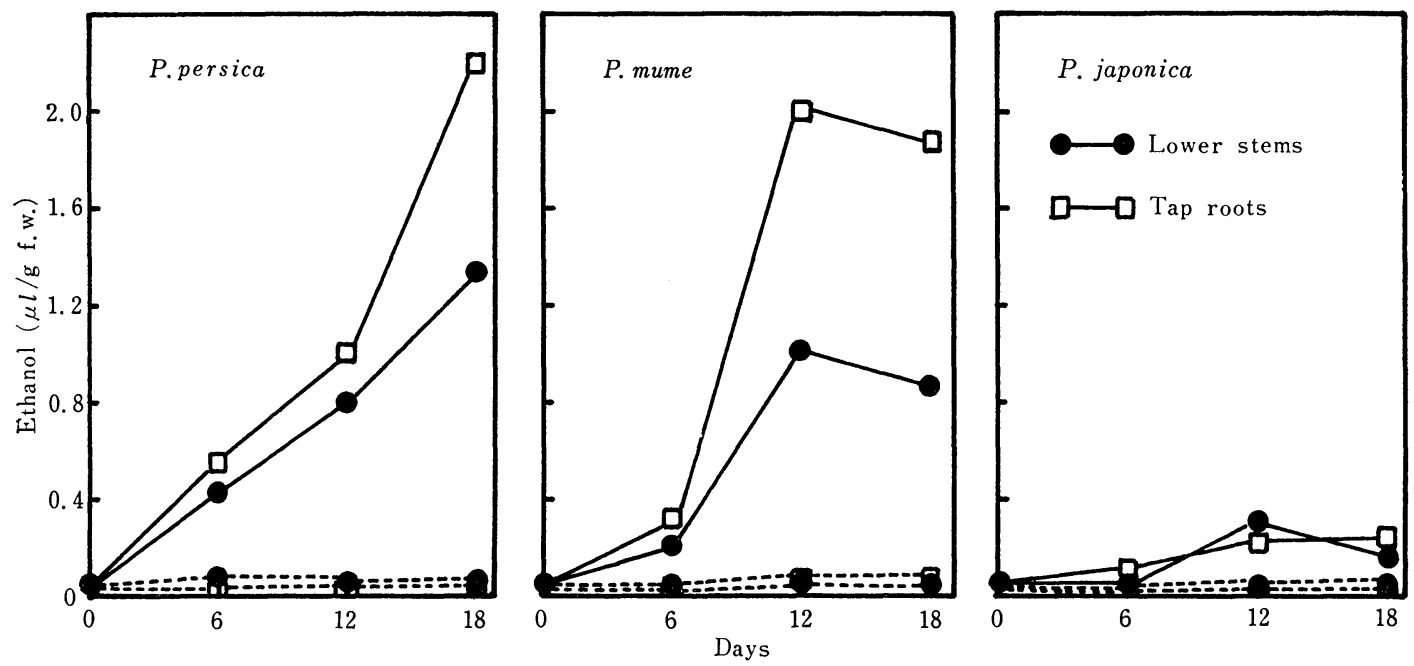

Fig. 3. Effect of waterlogging on ethanol accumulation in the lower stems and tap roots of Prunus species. Solid and dotted lines represent flooded and control plots, respectively. Plants were waterlogged for 18 days from June 29, 1979.

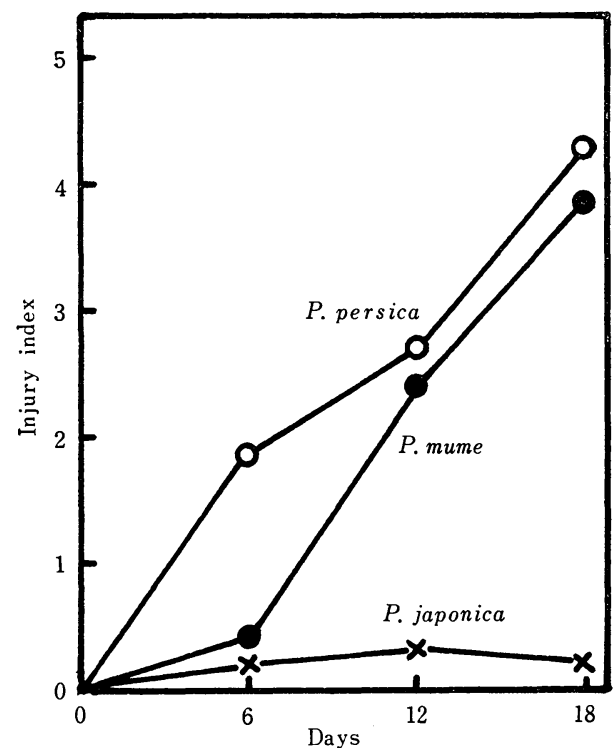

Fig. 4. Effect of waterlogging on injury symptoms of the above ground parts of Prunus species. Plants were waterlogged for 18 days from June 29, 1979. Injury index : $0=$ no visible injury, $5=$ plant death.

the stems of P. japonica(tolerant) and only a slight accumulation in those of Japanese plum(moderately tolerant).

No appreciable ethanol accumulation was found in the fine roots except for Japanese plum(Fig. 1), but differential ethanol accu- mulation was apparent in the tap roots between the water sensitive and tolerant species(Fig. 3).

Figs. 2 and 4 show the effect of waterlogging on the injury index of the above ground parts. Whereas peach and Japanese apricot developed a symptom of severe chlorosis and wilting of leaves, P.japonica and Japanese plum developed no or little injury symptoms during the waterlogged periods.

In a previous paper, we reported differences in water tolerance of several Prunus species in pot tests(7). Our present results showed that the sensitivity to waterlogging was closely related to ethanol accumulation in the tap roots and stems. P. japonica, which was most tolerant in our previous tests, accumulated much less ethanol than peach and Japanese apricot(Figs. 1,3). Crawford(3) and McManmon and Crawford(6) showed a close correlation between ethanol-accumulating species of Senecio and their sensitivety to waterlogging.

Catlin et al. (1) reported that rates of anaerobic production of ethanol by roots of willow and wignut(tolerant) and two walnut species(sensitive) were not consistent with differences in plant response to waterlogging. They insisted that after initial accumulation within roots, ethanol moved to the external 

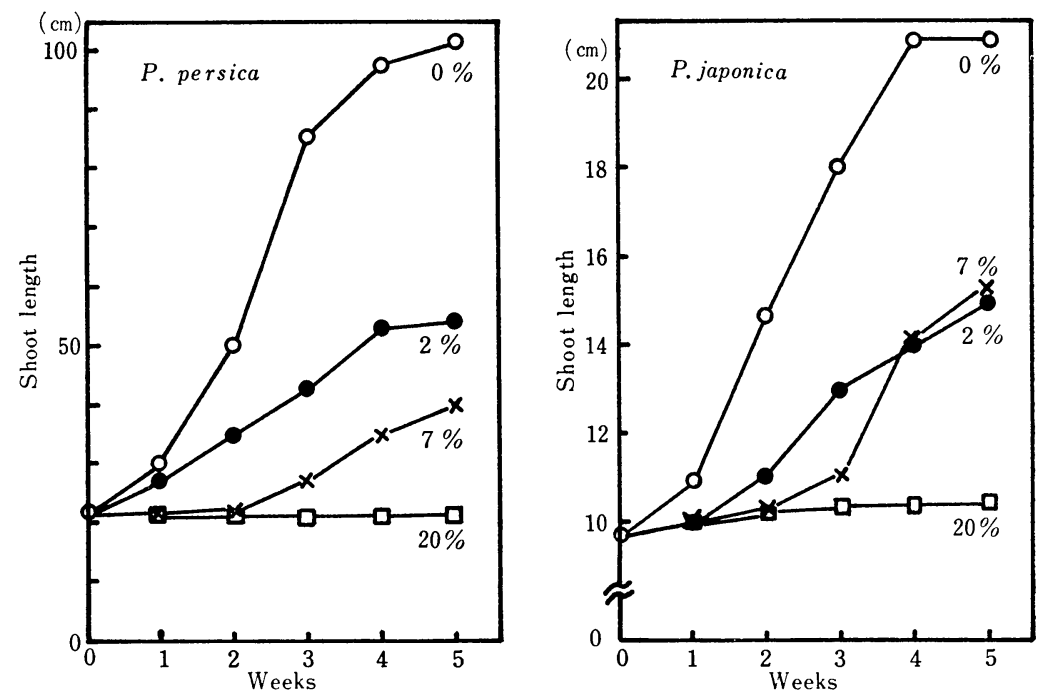

Fig. 5. Effect of a soil drench of aqueous ethanol on the shoot growth of peach and P. japonica seedlings.

Table 1. Effect of waterlogging on ethanol accumulation and injury symptoms of peach trees grafted on peach and P.japonica rootstocks.

\begin{tabular}{|c|c|c|c|c|c|}
\hline $\begin{array}{l}\text { Scion } \\
\text { cultivars }\end{array}$ & $\begin{array}{l}\text { Root- } \\
\text { stocks }\end{array}$ & $\operatorname{Parts}^{2}$ & $\frac{\text { Ethanol }}{\text { Control }}$ & $\frac{1 \text { content }}{1 \text { Flooded }}$ & $\begin{array}{c}\text { Injury } \\
\text { index }\end{array}$ \\
\hline \multirow{6}{*}{ Matsumoriwase } & \multirow{3}{*}{ Peach } & US & 0 & $\begin{array}{c}(\overline{\mu l / g} f \bar{w}) \\
1.16\end{array}$ & \multirow{3}{*}{3.7} \\
\hline & & $\mathrm{LS}$ & 0 & 2.66 & \\
\hline & & $\mathrm{R}$ & 0 & 4.45 & \\
\hline & \multirow{3}{*}{ P.japonica } & $\mathrm{US}$ & 0 & 0.04 & \multirow{3}{*}{1.0} \\
\hline & & L S & 0 & 0.49 & \\
\hline & & $\mathrm{R}$ & 0 & 1.27 & \\
\hline \multirow{6}{*}{ Ōkubo } & \multirow{3}{*}{ Peach } & US & 0 & 1.63 & \multirow{3}{*}{3.3} \\
\hline & & L S & 0 & 3.00 & \\
\hline & & $\mathrm{R}$ & 0 & 3.43 & \\
\hline & \multirow{3}{*}{ P. japonica } & US & 0 & 0.20 & \multirow{3}{*}{0.5} \\
\hline & & L S & 0 & 0.41 & \\
\hline & & $\mathrm{R}$ & 0 & 0.89 & \\
\hline \multirow{6}{*}{ Hakutō } & & US & 0 & 1.68 & \multirow{3}{*}{3.7} \\
\hline & Peach & L S & 0 & 4.13 & \\
\hline & & $\mathrm{R}$ & 0 & 5.15 & \\
\hline & \multirow{3}{*}{ P. japonica } & US & 0 & 0.55 & \multirow{3}{*}{1.0} \\
\hline & & L S & 0 & 0.63 & \\
\hline & & $\mathrm{R}$ & 0 & 1.48 & \\
\hline
\end{tabular}

z US : upper stems, LS : lower stems, R : roots.

y $0=$ no visible injury, $5=$ plant death.

environment. Our present results showed no or little accumulation in the fine roots of different Prunus species by flooding. In the case of fine roots, the ethanol produced under anaerobic conditions may easily move to the external environment.

The fact that ethanol was detected in the upper stems of peach and Japanese apricot only after 3 days of flooding(Fig. 1) indicates a rapid translocation of ethanol from roots to shoots. An apparent downward gradient of ethanol concentrations from roots to upper stems also suggests that the ethanol produced in the roots moved through the xylem to the above ground parts with transpiration stream (Table 1). Fulton and Erickson (5) showed that ethanol can be detected in the xylem sap of tomato plants under flooded conditions.

Fig. 5 shows the effect of a soil drench of ethanol on the shoot growth of young peach and P.japonica seedlings. Aqueous ethanol at a concentration of $20 \%$ completely inhibited the shoot growth of the two species. Even at $2 \%$ ethanol, the shoot growth was reduced to about $50 \%$ of the controls. The ethanol toxicity was slightly greater in peach than P.japonica when $7 \%$ ethanol was applied. As no marked difference was found in the toxic effect of exogenously applied ethanol between peach and $P$ japonica, the water tolerance of the latter is possibly 
due to the ability to avoid ethanol accumulation in the roots. Chirkova(2) reported the differetial tolerance to ethanol toxicity between water tolerant and sensitive species. He found that the superficially sterilized roots of rice and willow(tolerant) remained viable in $1 \mathrm{M}$ solutions of ethanol and lactate prepared with sterile distilled water, for a considerably longer time than the roots of wheat and poplar(sensitive). The roots of willow were killed in $1 \mathrm{M}$ solution in 3 days, in $10^{-1} \mathrm{M}$ in 7 days; while in poplar, the growing points of roots died off in the same concentrations in 2 and 4 days, respectively.

We previously reported that P.japonica, when used as a rootstock for peach, exhibited the greatest water tolerance among Prunus species examined(7). In this experiment, 3 scion cultivars of peach trees grafted on P. japonica showed greater tolerance than those on peach seedlings (Table 1). The rootstock effect on ethanol accumulation in the tap roots and stems under flooded conditions was shown in Table 1. In all combinations, the ethanol content was lower in the trees grafted on P.japonica than peach rootstocks.

Ethylene concentrations in the stems and roots were also lower in P. japonica than in peach seedlings under flooded conditions (8).

In conclusion, a mechanism(s) for avoiding the accumulation of anaerobic metabolites such as ethanol and ethylene is possibly involved in the water tolerance of $P$. japonica roots.

\section{Acknowledgment}

The authers wish to thank Dr. Kazuomi Kadoya, Professor of Ehime University, for reading this manuscript.

\section{Literature Cited}

1. Catlin, P. B., G. B. Vogel and E. A. Olsson. 1980. Ethanol production by roots and its role in differential sensitivity to waterlogging. HortScience $15: 407$.

2. CHIRKOVA, T. V. 1978. Some regulatory mechanisms of plant adaptation to temporal anaerobiosis. p. 137-154. In : D. D. Hook and R. M. M. Crawford (eds.) Plant life in anaerodic environments. Ann Arbor Sci. Pub. Michigan.

3. CRAWFORD, R. M. M. 1966. The control of anaerobic respiration as a determining factor in the distribution of genus Senecio. J. Ecol. $54: 403-413$.

4. CRAwFord, R. M. M. 1967. Alcohol dehydrogenase activity in relation to flooding tolerance in roots. J.exp. Bot. 18:458464.

5. Fulton, J.M. and A. E. ERICKSON. 1964. Relation between soil aeration and ethyl alcohol accumulation in xylem exudate of tomatoes. Soil Sci. Soc. Amer. Proc. 28 : $610-614$

6. MCMANMON, M. and R. M. M. CRAWFORD. 1971. A metabolic theory of flooding tolerance : the significance of enzyme distribution and behaviour. New Phytol. $70: 299-306$.

7. MizUTANi, F., M. YAMADA, A. SUgiuRA and T. TOMANA. 1979. Differential water tolerance among Prunus species and growth of peach scions on various kinds of rootstocks as affected by waterlogging. Studies from Inst. Hort. Kyoto Univ. $9: 28-35$. (In Japanese with English summary)

8. Mizutani, F. 1980. Studies on the replant problem and water tolerance of peach trees. Mem. Coll. Agr. Ehime Univ. 24:115198. (In Japanese with English summary)

9. Rowe, R. N. and D. V. BEARDSELL. 1973. Waterlogging of fruit trees. Hort. Abst. $43: 533-548$. 
核果類の耐水性と湛水条件下におけるエタノールの集積

水谷 房 雄 $^{1} \cdot$ 山田 昌 彦 $^{2} \cdot$ 苫 名 孝
京都大学農学部 606 京都市左京区

摘 要

核果類の耐水性の強弱と湛水条件下に拈ける樹体内で 下におケる樹体内のエタノール集積もより少なくなっ のエタノール集積との間に関係があるかどらかを調査し た. 細根では, いずれの種においても顕著なェタノール の集積が認められなかったが，主根や茎では，耐水性の 弱い種において著しい集積が認められた。湛水処理後, モモとウメでは急速なエタノール集積が認められたも のの，日本スモモではわずかしか，またニワウメではほ とんぞ集積が認められなかった．モモの台木として， = ワウメを用いると共台に比べ耐水性が増大し, 湛水条件 た.

$2,7,20 \%$ のエタノール溶液を土壤灌注して, モモと ニワウメの実生の生育を調査したところ，7\% 処理区で ニワウメはモモよりもエタノールに対して耐性を示した が，全体的にみて両者の間にエタノールに対する耐性の 違いは認められなかった。

1 現在 : 愛媛大学農学部

2 現在 : 果樹試験場安芸津支場 